\title{
Auditor Compensation Pattern Of S\&P 500 Corporations Before And After The Passage Of Sarbanes-Oxley Act
}

Ganesh M. Pandit, (E-mail: pandit@adelphi.edu), Adelphi University

Vijaya Subrahmanyam, Mercer University, Atlanta

Allen Rubenfield, Clark Atlanta University

\begin{abstract}
The years 2001-02 were marked with an outburst of huge corporate financial failures that eroded billions of dollars from the stockholders' equity and shook the confidence of the investor community. One of the issues that rose to the surface was the payment of huge nonaudit service fees by publicly traded companies to their auditors. In response to the outcry against the alleged role of the auditors in the corporate scandals, Congress passed Sarbanes-Oxley Act of 2002 (SOX), which imposed a prohibition on the supply of certain nonaudit services by a CPA firm to its audit clients in order to reduce the suspected revenue-dependence of auditors on their audit clients. The study described in this paper examines the pattern of auditor compensation in the years 2001 and 2004 (i.e., pre-and post-SOX periods), for a sample of large public companies, to determine how the auditor compensation has changed during this three-year period and whether the new regulations have decreased such revenue-dependence of the auditor. The study also examines if each of the Big 4 CPA firms that dominate the audit market for large public companies have experienced a change in the pattern of their revenues drawn from different sources of auditor compensation. The results show that not only the composition of auditor compensation has changed after the passage of SOX but also the overall compensation paid by the sampled companies to their auditors has gone up noticeably in many cases, primarily due to a phenomenal rise in audit fees, which still may continue to threaten the auditor's independence in the audit process. Further, during this three-year period, each of the Big 4 CPA firms has shifted its emphasis on the different sources of its revenues from these large public companies.
\end{abstract}

\section{INTRODUCTION}

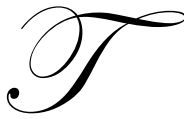

he issue of auditor compensation has attracted the attention of academia for many years, and more recently the huge corporate scandals have created a new furor of interest in the topic. In the past, some studies focused on the relationship of auditor compensation with the risk of exposure to future losses from client's failure (Beatty 1993), client satisfaction (Behn et al. 1999), determinants of audit fees (Taylor and Simon 1999), or audit quality (Hogan 1997; Simon 1997; Craswell et al. 2002; Ascioglu et al. 2005). In the recent years, the focus shifted to auditor compensation, particularly the fees received from the provision of nonaudit services, and the perceived independence of auditor. Different researchers found contradicting evidence about the hypothesized relationship between nonaudit fees and auditor's perceived lack of independence (Dee et al. 2002; DeFond et al. 2002; Frankel et al. 2002; Ashbaugh et al. 2003; Ashbaugh 2004; Ferguson et al. 2004).

The surge in the research on auditor compensation from non-audit services and auditor's perceived (lack of) independence was accompanied by news reports about the soaring amounts of non-audit service fees (Kelly 1999; Weil and Tannenbaum 2001; Brubaker 2002; Stock 2002), and the government's efforts to bring more transparency in the disclosure of auditor-client relationship with reference to the amount of revenues received by the audit firm from 
its audit clients ( $\left.\mathrm{SEC}^{1} 2000\right)$. In requiring the publicly traded companies to disclose the amount of non-audit fees paid via their annual proxy statements, the government expressed a concern about the phenomenal rise in the non-audit fees that exceeded the audit fees paid by the these companies and its possible impact on the stakeholders' perception of the auditor's independence. The corporate scandals at the beginning of this decade dealt the final blow to this issue and prompted the government to pass a new legislation, namely, the Sarbanes-Oxley Act of 2002 (SOX), which made sweeping changes in the area of financial reporting and auditing.

The current study examined the components of total compensation received by the auditors of a sample of Standard \& Poor's Index of 500 (S\&P500) companies with reported annual revenues of $\$ 1$ billion or more for the calendar years 2001 and 2004. The purpose was to determine if subsequent to the passage of certain requirements of SOX, the pattern of total auditor compensation paid by the large companies has changed. The SOX requirements in question include (1) prohibition on the provision of certain non-audit services by auditors to their audit clients, and (2) the auditors' mandatory attestation of the management's assessment of the internal control over financial reporting of the audit client. Since these companies are very large players in the capital markets, their investors are expected to be watchful about both the independence of their auditors and the assurance of integrity of their financial statements, and hence fees paid to their auditors are likely to be monitored carefully by the investors. Besides, all of these companies are accelerated filers, and hence, they were required to comply with the internal control reporting requirement of SOX for the calendar year 2004 (SEC 2003b; SEC 2004).

All of these companies were audited by one of the Big 4 CPA firms during the years of study. ${ }^{2}$ Therefore we also studied if there was a change in the pattern of the revenue streams of these four CPA firms in relation to the fees received from the sampled companies. The results of the research showed that subsequent to the passage of SOX, there was an obvious decrease in the amount of the non-audit service fee component of the total auditor compensation. However, during the same period, there was a considerable increase in the amount of audit fees, which caused the overall auditor compensation to rise in the post-SOX period. Further, there was a noticeable change in the pattern in which each of the Big 4 CPA firms drew their revenues from the sampled companies before and after the passage of SOX. The rest of the paper describes the prior literature related to the topic of auditor compensation, motivation for and purpose of the current study, collection of the data and description of the sample, findings and concluding remarks.

\section{LITERATURE REVIEW}

Research in the nineties mostly concerned itself with determinants of auditor compensation. Beatty (1993) found that auditors charged higher fees to cover their exposure to losses for clients that had the potential to fail in the immediate future, while Simon (1997) investigated if higher auditor fees were related to higher audit quality delivered by the largest few CPA firms. Hogan (1997) found that clients that chose higher audit quality (indicated by the choice of a Big 6 audit firm) paid higher auditor fees but reduced their overall costs of the IPO by minimizing the under-pricing of the IPO. Also, Taylor and Simon (1999) indicated that the fear of litigation and increase in regulatory disclosure requirements had a positive association with the rise in audit fees.

With the recent corporate scandals and the role of the auditor in this regard, the interest in the research on auditor compensation continued into the current decade. In fact, increasing reports about rising non-audit fees and the SEC's concern about the possible compromise of auditor's independence as well as the SEC Final Rule Release No. 33-7919 (2000) pertaining to the specific disclosure of non-audit fees in the clients' proxy statements prompted more research related to auditor compensation. Several researchers found mixed and hence non-conclusive evidence about the existence of large non-audit fees and their role in the weakening of auditor independence. On the one hand, Frankel et al. (2002) concluded that non-audit service fees were positively associated with the incidence of earning management in their sampled companies. Dee et al. (2002) argued that auditors might be less diligent in curbing income-increasing earnings management practices from clients from whom they received high proportions of non-

\footnotetext{
${ }^{1}$ U.S. Securities and Exchange Commission.

2 These firms are Deloitte \& Touché LLP (D\&T), Ernst \& Young LLP (E\&Y), KPMG LLP (KPMG), and PricewaterhouseCoopers LLP (PWC).
} 
audit service fees. Firth (2002) found that companies that paid higher amounts of consultancy fees to their auditors were more likely to receive clean audit opinions. Ferguson et al. (2004) concluded that "higher levels of economic bonding between auditor and client resulting from the joint provision of [non-audit services] may reduce auditors' willingness to restrain clients' opportunistic accounting practices and, in turn, may reduce the quality of financial reporting" (p. 836). More recently, Krishnan et al. (2005) found that investors perceived auditors' independence to be compromised by the provision of non-audit services to their audit clients.

On the other hand, Craswell et al. (2002) indicated that higher auditor compensation did not necessarily result in a lower propensity for the auditor to issue a qualified audit opinion. Also, Ascioglu et al. (2005) found weak evidence in support of the magnitude of auditor compensation and the quality of client's disclosures and hence questioned the wisdom of the recent prohibition on non-audit services by SOX. Other researchers also claimed that no such relationship existed between the existence of non-audit fees and auditor's perceived lack of independence or the propensity to be in agreement with the client's management (DeFond et al. 2002; Raghunandan 2003; Raghunandan et al. 2003; Ashbaugh et al. 2003; Geiger and Rama 2003).

\section{PURPOSE OF THE STUDY}

Regardless of what the empirical research in this area suggests, the issue of large non-audit service fees and their potential effect on the auditor's perceived independence received serious attention when the SEC (2000) began requiring public companies to disclose the details of the compensation received by their auditors during the fiscal year in their proxy statements or the periodic annual filing. In mandating this disclosure, the SEC (2000) emphasized the role of the audit in improving the credibility of financial statements and in creating and promoting public confidence in the financial reporting process. The SEC further emphasized the importance of auditor's independence in the audit of the financial statements of publicly traded companies because the investors in these companies rely on the work of the auditor in ensuring the integrity of their financial statements. The SEC expressed a growing concern about the rise in the amount of non-audit service fees as a component of the total auditor compensation, which could impair the objectivity of the auditor and have harmful effects on the capital allocation process in the economy. Yet, instead of imposing a total ban on non-audit services, starting with the most recent fiscal year, the registrant companies were required only to disclose their auditor compensation under three categories, viz., audit fees, financial information systems design and implementation (FISDI) fees, and all other fees that included tax-assistance, mergers and acquisition support, etc. (SEC 2000).

In the subsequent years, the SEC (2003a) modified its auditor compensation disclosure rules and directed the registrants to disclose the details of auditor compensation in four specific categories, viz., audit fees, audit-related fees, tax fees, and all other fees, for each of the two most recent fiscal years in their annual proxy statements or periodic annual filings. The purpose of these new disclosure requirements was to comply with the mandate of SOX regarding the disclosure of approved non-audit services and provide increased "transparency" of information to investors. As a result of these developments, the information about fees paid to auditors for various types of non-audit services became publicly available, and the readers of proxy statements also discovered that the amount of fees paid to auditors for services other than the audit work had reached phenomenal levels. Table 1 below summarizes the distribution of auditor compensation paid by the S\&P500 Index companies for the year 2001.

As shown in the table, for 2001, almost $73 \%$ of the total compensation paid to auditors arose from providing non-audit services to these companies. A major portion of the non-audit fees was paid for other services, some of which consisted of fees for "non-financial information system design and implementation services", also referred to as consulting services in the past. Approximately one-sixth of this group of companies paid 80 percent or more of their total auditor compensation for non-audit services. Also, almost four-fifths of these companies paid more than 50 percent of their total auditor compensation for non-audit services. This phenomenal increase in the amount of nonaudit fees and its proportion in the total fees paid to the auditor, combined with the recent wave of corporate scandals, brought to the forefront the topic of economic bonding between clients and their audit firms, and its potential impact in compromising the auditors' independence in the audit process. As Dickins and Higgs (2005) discussed, if the ratio of non-audit fees to the total fees is any indicator of the auditor's impaired independence, the above statistics clearly should have created a doubt about the perceived independence of the audit firms in 2001. 
Table 1

Breakdown Of Auditor Compensation Paid During 2001 By The S\&P500 Companies ${ }^{3}$

\begin{tabular}{|c|c|}
\hline Type of Service Provided by the Auditor Firm & Percent of Total Auditor Compensation \\
\hline Audit Fees & $27.4 \%$ \\
\hline Non-audit Fees & $72.6 \%$ \\
\hline & \\
\hline Non-audit Fees consisted of & $11.4 \%$ \\
\hline Audit-Related Fees* & $11.1 \%$ \\
\hline FISDI Fees** & $13.3 \%$ \\
\hline Tax Related Fees & $36.8 \%$ \\
\hline Other/Miscellaneous Fees*** & $72.6 \%$ \\
\hline
\end{tabular}

* Fees for assurance and related services, that are not included in the Audit Fees

** Fees for the financial information systems design and implementation services

*** Includes fees for various activities not included under FISDI Fees, Audit-Related Fees and Tax Fees

In order to strengthen the prohibition on the sale of non-audit services by audit firms to their audit clients, the SEC (2003a) removed certain past exceptions to such prohibition and began to require the provision of allowable nonaudit services to be pre-approved by the audit committees of the clients, specifically in response to the requirements of SOX. The SEC also required the listed companies to disclose in "qualitative terms" the nature of services provided under the three categories of fees other than the audit fees. In imposing these rules, the SEC (2003a) made it clear that "(1) an auditor cannot function in the role of management, (2) an auditor cannot audit his or her own work, and (3) an auditor cannot serve in an advocacy role for his or her client," because violation of these principles would impair the auditor's independence in the audit.

An important factor behind the SEC's revised rules for the disclosure of auditor compensation by the registrant companies was the new requirements of SOX. The recent wave of corporate failures (e.g., Enron, WorldCom, Adelphia, etc.) and the restatements of previously published financial statements by several publicly traded companies had investors question the relationship between the corporate management and the auditors who were earning huge amounts of consulting and other "non-audit" service fees. The disproportionate amount of nonaudit service fees paid to auditors raised the issue of auditor independence, which combined with the public outcry against the huge corporate failures, finally led Congress to pass SOX.

Since the Securities legislations of 1930s, there has been no bigger piece of legislation with such far-reaching impact on the financial reporting than SOX of 2002. At a minimum, SOX includes certain provisions that are intended to curb the perceived fee-dependence of auditor firms on their audit clients. Sections 201, 202 and 404 of SOX are likely to have a significant impact on the compensation patterns of all CPA firms that provide services to the publicly traded companies. The current research examined the impact that these new legislative requirements may have had on the auditor compensation pattern of publicly traded companies in the year after the requirements of SOX became effective for the large companies.

Pursuant to Section 201 of SOX, the SEC has adopted rules that specifically prohibit auditors of publicly traded companies from providing certain non-audit services to their audit clients. The nine categories of non-audit services prohibited by SOX and the SEC's Final Release No. 33-8183 (SEC 2003a) are: (1) Bookkeeping or other services related to the accounting records or financial statements of the audit client; (2) Financial information systems design and implementation; (3) Appraisal or valuation services, fairness opinions, or contribution-in-kind reports; (4) Actuarial services; (5) Internal audit outsourcing services; (6) Management functions or human resources; (7) Broker or dealer, investment adviser, or investment banking services; (8) Legal services and expert services unrelated to the audit; and (9) Any other service that the Public Company Accounting Oversight Board determines, by regulation, is 3 This is based on the data gathered from the 2003 proxy statements of these companies that contained the data for the calendar
years 2002 and 2001 . 
impermissible. In adopting these rules, the SEC once again emphasized the independence of auditors and reiterated the need for the auditors to remain separated from the audit clients and not be an advocate of the client's management. This prohibition on the non-audit services has the potential to cause a significant dip in the revenues of the CPA firms that serve publicly traded companies especially since a large portion of the audit firms' revenues arose from non-audit fees prior to SOX. Therefore, other things remaining the same, we expected the overall compensation paid by our sampled companies to their auditors in the post-SOX period to be lower than that during the pre-SOX period.

Section 202 of SOX requires public companies to obtain pre-approval of their audit committees prior to buying auditing services and certain non-prohibited non-audit services (including tax services) from their auditors. However this pre-approval requirement is waived if the amount of non-audit services provided to the company does not exceed five percent of the total compensation paid to the auditor by the company during the fiscal year when the services are provided (SEC 2003a). In view of this de minimis exception, we expected that in order to avoid the preapproval requirement, companies might try to keep the amount of "all other fees" below the required limit of five percent of the total compensation paid to the auditor. The "all other fees" component of the total fees was considered the appropriate candidate for the companies to take benefit of the de minimis exception because of the objections raised by the SEC (2000) against the magnitude of these fees in the years prior to SOX.

Section 404 of SOX, followed by the SEC Final Rule Release No. 33-8238 (SEC 2003b), requires a publicly traded company, to include in its annual report an "internal control report" containing a statement about the responsibility of the management for establishing and maintaining adequate internal control and procedures for financial reporting. The report also has to include the management's assessment of the effectiveness of the said internal control. In addition, the law requires the auditor to attest to and report on the assessment made by the management of the said internal control structure. The requirement became effective for the first fiscal year ending on or after November 15, 2004 for accelerated filers, where accelerated filers are companies with a public float of at least $\$ 75$ million, that have been subject to the Exchange Act's reporting requirements for at least 12 calendar months and that previously have filed at least one annual report (SEC 2004). This new requirement potentially increases the work of auditors who already are under increased pressure to be more vigilant in their performance of the audits in wake of the recent corporate failures. As Scott (2003) describes, in a survey of Financial Executives International (FEI) members, the estimates for the number of additional man hours needed to comply with the SOX requirements were as high as 65,000 hours, some of which was for the attestation time. Also, according to Levinsohn (2004), in another survey of the FEI members, results showed that the external audit fees were expected to rise by as much as 40 percent due to the compliance with section 404 of SOX. Therefore, we expected that the need for compliance with Section 404 of SOX would cause audit fees to go up starting with the year 2004. This expectation also is supported by other literature in this regard (Cohen and Vecchio 2004; Salierno 2004) as well as the news reports in the days following the implementation of the provisions of SOX (Weil 2004; Gullapalli 2005).

Additionally, we explored if, subsequent to the implementation of these new provisions, there was a change in the pattern in which each of the Big 4 CPA firms drew their revenues from each of the four major sources of auditor compensation as identified by the SEC (2003a). Prior to these legislative changes, the Big 4 CPA firms had auditing and consulting relationships with their audit clients. Subsequently, they spun off their consulting services in order to stay compliant with the legislative changes. Since the "other fees" component of the total auditor compensation was affected the most by the requirements of SOX, we expected that each of the Big 4 CPA firms would compensate for the decline in the "other fees" component by trying to raise their revenues from each of the remaining three sources of compensation. Thus, other things remaining the same, concurrent with the fall in the "other fees", the revenues from audit fees, audit-related fees and tax fees should rise, although not necessarily in the same proportion since there is a bigger demand for audit services compared to the other two types of services.

\section{COLLECTION OF THE DATA AND DESCRIPTIVE STATISTICS}

The data for this study were obtained from the proxy statements of a sample of S\&P500 companies. The reason for selecting the S\&P500 companies was to examine the auditor compensation disclosures of the accelerated filers, i.e., the large companies that were supposed to comply with the internal control reporting requirements of SOX starting with the fiscal year ending on or after November 15, 2004 (SEC 2004). The initial group of 500 companies 
was screened further by examining their reported revenues for the years 2001 and 2004 to include only the companies whose revenues exceeded $\$ 1$ billion. The threshold of $\$ 1$ billion in revenues was chosen to focus on those companies that were relatively large in size and had much at stake in terms of their reputation should their auditors be perceived as "lacking in independence" because of the amount of fees paid to them. Further, in order to maintain comparability among the companies, we excluded all companies whose accounting year ended on dates other than December 31 . A secondary purpose of this research was to examine the redistribution of the revenue streams among the Big 4 CPA firms. To accomplish this purpose, we excluded companies that were audited by the non-Big 4 CPA firms. The resulting sample contained three hundred and twelve companies.

Table 2

\section{Descriptive Statistics On The Sampled Companies ${ }^{4}$}

\begin{tabular}{|c|c|c|}
\hline \multicolumn{2}{|l|}{ Percentage of Companies traded on the NYSE } & $91.5 \%$ \\
\hline \multicolumn{2}{|l|}{ Percentage of Companies traded on the NASDAQ Market } & $8.5 \%$ \\
\hline Percentage of Companies audited by the Big CPA firms ${ }^{5}$ & In 2001 & In 2004 \\
\hline Audited by Arthur Andersen, LLP (AA) & $20.7 \%$ & ---- \\
\hline Audited by Deloitte and Touché, LLP (D\&T) & $15.0 \%$ & $20.3 \%$ \\
\hline Audited by Ernst and Young, LLP (E\&Y) & $23.5 \%$ & $29.2 \%$ \\
\hline Audited by KPMG, LLP (KPMG) & $9.8 \%$ & $15.0 \%$ \\
\hline Audited by Pricewaterhousecoopers, LLP (PWC) & $30.9 \%$ & $34.9 \%$ \\
\hline \multicolumn{3}{|l|}{ Percentage of companies from different industry categories based on NAICS ${ }^{6}$ : } \\
\hline \multicolumn{2}{|l|}{ Commodity Services and Supplies (Electricity, Gas, Paper products, etc) } & $13.0 \%$ \\
\hline \multicolumn{2}{|l|}{ Financial Services (Banking, insurance and investment banking) } & $23.5 \%$ \\
\hline \multicolumn{2}{|l|}{ Healthcare and Professional Services (laboratories, advertising) } & $5.0 \%$ \\
\hline \multicolumn{2}{|l|}{ Manufacturing } & $35.2 \%$ \\
\hline \multicolumn{2}{|l|}{ Mining, Drilling and Extraction } & $10.5 \%$ \\
\hline \multicolumn{2}{|l|}{ Non-professional Services (Cable, newspaper, radio, etc) } & $5.7 \%$ \\
\hline \multicolumn{2}{|l|}{ Other (Railroads, restaurants, hotels, etc) } & $7.1 \%$ \\
\hline
\end{tabular}

Table 2 above presents some descriptive statistics about the companies included in the sample. As noted in Table 2, the sample covered a broad cross section of the overall audit market which included companies in a wide variety of industries including manufacturing, banking, healthcare and various professional and non-professional services. The largest share for the audit market of the sampled companies was claimed by PWC, in both 2001 and 2004. In general, the Big 4 CPA firms maintained their relative rankings in the market for the audit of S\&P500 companies based on their respective market shares, in both years under study.

According to Table 3, since 2001, within our sample sub-set of the S\&P500 companies, D\&T and KPMG increased the number of their clients in approximately equal numbers while E\&Y claimed the most (19) and PWC received the fewest (13) in new clients. In terms of the percentage gains in clientele, PWC experienced a relatively smaller gain (13\%) over its previous client-base while KPMG showed the largest gain (53\%) in clientele. We did not examine to see how much of this gain in audit clients for each Big 4 CPA firm was the direct result of the closure of AA, and how much was because of the switching of auditors on the part of the companies.

4 Some of the percentage totals may not add up to $100 \%$ because of the rounding off.

5 In the year 2001, the sampled companies were audited by the Big Five CPA firms including Arthur Andersen, which went out of existence in 2002.

6 North American Industry Classification System. 
Table 3

Detailed Statistics On The Market Shares Of The Big CPA Firms Among The Sampled Companies In 2001 And 2004

\begin{tabular}{|l|c|c|c|c|}
\hline & D\&T & E\&Y & KPMG & PWC \\
\hline No. of sampled companies audited in 2001 & 47 & 73 & 30 & 97 \\
\hline $\begin{array}{l}\text { Total Fees (\$) paid by the sampled companies in 2001 } \\
\text { to each Big 4 CPA firm }\end{array}$ & $\$ 555$ million & \$572 million & \$327 million & \$1,484 million \\
\hline & & & & \\
\hline Number of new clients gained since 2001 & $\mathbf{1 7}$ & $\mathbf{1 9}$ & $\mathbf{1 6}$ & $\mathbf{1 3}$ \\
\hline & & & 46 & 110 \\
\hline No. of sampled companies audited in 2004 & 64 & 92 & 46 \\
\hline $\begin{array}{l}\text { Total Fees (\$) paid by the sampled companies in 2004 } \\
\text { to each Big 4 CPA firm }\end{array}$ & $\$ 801$ million & \$779 million & $\$ 584$ million & $\$ 1,548$ million \\
\hline
\end{tabular}

* In 2001, 65 companies in the sample were audited by AA that received $\$ 456$ million in compensation.

We also observed that in 2001, the smallest percentage of the total fees paid by a company for non-audit services was 19 percent, paid primarily for audit-related and tax services, while the largest such percentage was 96 percent, paid by a company primarily for other services. At the same time, the smallest dollar amount of non-audit service fees paid by a company was less than $\$ 125,000$ while the largest such amount was $\$ 85.9$ million, of which more than 50 percent was paid for FISDI and other/miscellaneous services. In 2004, the picture changed significantly, both in quantitative and qualitative terms. The smallest percentage of total fees paid for non-audit services by a company was 0.3 percent, incurred for audit-related services, while the largest such percentage was 69 percent, paid mainly for audit-related and tax-related services. Also, for 2004, the smallest amount of non-audit service fees paid by a company was $\$ 13,000$ while the largest such amount was $\$ 56.5$ million, incurred mainly for audit-related and tax-related services.

While, in 2001, forty-nine companies (or about 16 percent of the sample) paid 80 percent or more of their auditor compensation for non-audit services; in 2004, no company paid more than 69 percent of its auditor compensation in the form of non-audit fees. Also in 2004, only nine companies (or 3 percent of the sample) paid 50 percent or more of their total fees for non-audit services. This was in sharp contrast to the situation in 2001 where two hundred and forty-eight companies (or 79 percent of the sample) paid 50 percent or more of the total auditor compensation for non-audit service fees. A summary of these observations is presented in Table 4 below.

Table 4

Summary Of Observations About Total Non-audit Service Fees Paid By The Sampled Companies In 2001 And 2004

\begin{tabular}{|l|c|c|}
\hline \multicolumn{1}{|c|}{ Type of observation } & $\mathbf{2 0 0 1}$ & $\mathbf{2 0 0 4}$ \\
\hline Smallest percentage of total fees paid as non-audit service fees by a company & $19 \%$ & $0.3 \%$ \\
\hline Smallest amount paid as non-audit service fees by a company & $\$ 125,000$ & $\$ 13,000$ \\
\hline Largest percentage of total fees paid as non-audit service fees by a company & $96 \%$ & $69 \%$ \\
\hline Largest amount paid as non-audit service fees by a company & $\$ 85.9$ million & $\$ 56.5$ million \\
\hline $\begin{array}{l}\text { Percentage of companies that paid at least 80\% of their auditor compensation for non- } \\
\text { audit services }\end{array}$ & $16 \%$ & $0 \%$ \\
\hline $\begin{array}{l}\text { Percentage of companies that paid more than 50\% of their auditor compensation for non- } \\
\text { audit services }\end{array}$ & $79 \%$ & $3 \%$ \\
\hline
\end{tabular}


We gathered all relevant information on auditor compensation for the 312 companies from their relevant proxy statements. ${ }^{7}$ Each proxy statement provided details of the auditor compensation including the specific amounts paid for the four components, namely, (a) audit fees, (b) audit-related fees, (c) tax fees, and (d) all other fees. Using this data, we compared the summary numbers for the four components of auditor compensation paid by the sampled companies across the two years under study. Further, we compared the total fees received by the Big 4 CPA firms for each of the four major components in 2001 and 2004 to examine if each of the four firms was receiving significantly more or less compensation in each of the four areas of auditor compensation in 2004, as compared to that in 2001. Results of the data analysis are presented in the following section.

\section{FINDINGS AND DISCUSSION}

The current rules require public companies to classify total auditor compensation into four designated categories, referred to earlier, in the annual proxy statement with a general description of the services performed under each category. However, it was not possible for us to determine with 100 percent certainty if any of the sampled companies "rebundled" some of the non-audit service fees, especially the audit-related fees ${ }^{8}$, into the audit fees category to minimize the amount of total non-audit service fees reported for 2004 . This is especially so since by definition, audit-related fees are fees for services that typically are provided by external auditors for assurance and related services and are reasonably related to the performance of the audit (SEC 2003a). In addition, the SEC also expanded the definition of the term "audit fees" to include services such as comfort letters, international statutory audits, attestation services related to SEC registration statements, etc. (SEC 2003a). Thus, the line of distinction between the two categories of fees may become blurred and in fact, reduce the transparency of auditor compensation disclosures.

\section{General Findings}

Comparing across the two years, 2001 and 2004 (i.e., pre- and post-SOX), the results showed that the percentage of aggregate auditor compensation paid by the sample for various non-audit services dropped from 71 percent in 2001 to 25 percent in 2004, which also meant that the percentage of aggregate auditor compensation paid towards audit fees soared from 29 percent in 2001 to 75 percent in 2004. These results are summarized in Table 5 that provides a quick comparison between the different components of auditor compensation paid by the sample during 2001 and 2004.

In the non-audit service fees category, the percentage of total auditor compensation paid for audit-related services dropped from 15 percent in 2001 to 10 percent in 2004. The payments for FISDI services dropped from 10 percent in 2001 to zero percent in 2004, mainly because the provision of FISDI services by the external audit firm to its audit clients is prohibited by SOX. The percentage of total fees paid for tax-related matters decreased from 15 percent in 2001 to 14 percent in 2004 for the sample. The reason for this decrease is unclear from the limited information given in the proxy statements. The total amount paid for "all other fees" dropped from 31 percent of the total auditor compensation in 2001 to a little more than 1 percent in 2004. The significant drop in "all other fees" was not surprising especially in the light of the prohibition on the provision of many of these services by the auditors to their audit clients pursuant to SOX and the related rule of the SEC (2003a).

\footnotetext{
${ }^{7}$ In order to gather the auditor compensation information under the four categories for the year 2001, we had to refer to the 2003 proxy statements that contained the information for both 2002 and 2001. This is because prior to 2002, companies were required to provide the details for only three categories, viz., audit fees, FISDI fees, and all other fees.

${ }^{8}$ Examples of audit-related services include benefit plan audits, due diligence with respect to mergers and acquisitions, and internal control reviews (SEC 2003a).
} 
Table 5

Breakdown Of Auditor Compensation Paid During 2001 And 2004

\begin{tabular}{|l|c|c|}
\hline $\begin{array}{l}\text { Type of Service Provided by the Audit Firm to its audit } \\
\text { clients }\end{array}$ & $\begin{array}{c}\text { Percent of Total Auditor } \\
\text { Compensation during 2001 }\end{array}$ & $\begin{array}{c}\text { Percent of Total Auditor } \\
\text { Compensation during 2004 }\end{array}$ \\
\hline Audit Fees & $28.7 \%$ & $75.1 \%$ \\
\hline Non-audit Service Fees & $71.3 \%$ & $24.9 \%$ \\
\hline & & \\
\hline Non-audit Fees consisted of & & $9.8 \%$ \\
\hline Audit-Related Fees & $15.4 \%$ & $0.0 \%$ \\
\hline FISDI Fees & $10.1 \%$ & $13.7 \%$ \\
\hline Tax Fees & $14.6 \%$ & $1.4 \%$ \\
\hline All Other Fees & $\underline{31.1 \%}$ & $24.9 \%$ \\
\hline
\end{tabular}

While some companies still may be spending relatively significant amount of money on purchasing non-audit services from their auditors, there appeared to be an overall downward shift in the amount of non-audit services bought by public companies from their auditors, as one might expect following the passage of SOX. Our finding was in conformity with a report by the Professional Oversight Board for Accountancy (Reynolds 2005) that reported that the Big 4 CPA firms that audit the larger companies had experienced a steep decline in their non-audit service revenues from their audit clients in the recent years. It also confirmed the results of a 2002 Investor Responsibility Research Center survey described by Salierno (2002), which found that following the aftermath of the corporate scandals, companies were buying less non-audit services, especially IT services from their audit firms.

\section{Overall Auditor Compensation In The Pre- And Post-SOX Period}

The aggregate amount of non-audit service fees paid by the entire sample declined from approximately $\$ 2.4$ billion paid during 2001 to $\$ 924$ million during 2004, a decrease of 62 percent over the three-year period. Further, two hundred and sixty-five companies (or approximately 85 percent of the sample) incurred lower non-audit service fees in 2004 compared to that in 2001. Despite the significant decrease in the non-audit service fee component, the aggregate auditor compensation paid by the sample increased, in absolute terms, from approximately $\$ 3.4$ billion during 2001 to $\$ 3.7$ billion in 2004, an increase of $9.4 \%$ over the period. Majority of the increase in the total auditor compensation resulted from a large increase in "audit fees." In fact, due to the increase in the audit fees component, the total compensation paid to the auditor in 2004 (the post-SOX period) was higher than that in 2001 for each of the two hundred and twenty-seven companies (or 73 percent) in the sample). Among these, fifty-five companies (or 17.6 percent of the sample) experienced a 100 percent or larger increase in total fees paid to their auditors in 2004 compared to that in 2001. So the result was contrary to our expectation that the overall auditor compensation would decline significantly in 2004 compared to that in 2001, given the prohibition imposed by SOX and the SEC (2003a) on the provision of several non-audit services by the audit firms to their audit clients.

The SEC (2003a) questioned the large amount of revenues received by the audit firms from the provision of non-audit services to their audit clients and intended to reduce the "revenue-bonding" between a company and its audit firm by using a combination of (i) prohibition on the sale of certain non-audit services by an audit firm to its audit clients and (ii) requiring a disclosure of the total compensation paid to the auditors in the annual proxy statements. While the SEC may have achieved the goal of reducing non-audit service fees, the findings indicate that the increase in the total auditor compensation in the post-SOX period may not have resolved the issue of audit firms' fee-dependence on their clients. While a sub-set of academia and the government have been concerned with the role of non-audit fees in compromising the perceived independence of the auditor, there are others that believe that it is the total amount of compensation paid to the auditor that has the potential to impact the auditor's independence (Dickins and Higgs 2005). The findings in the current research show that several large companies are paying larger fees overall to their audit firms in the post-SOX period except that now it may be categorized under audit fees.

\footnotetext{
${ }^{9}$ The total does not add up to $71.3 \%$ because of rounding-off differences.
} 


\section{Use Of The De Minimis Exception By The Sampled Companies}

We expected the companies to reduce the purchase of certain non-prohibited non-audit services to less than five percent of the total compensation paid to their audit firms in order to avoid seeking pre-approval of the audit committees in accordance with the requirements of SOX and the SEC (2003a). Our findings showed that in the preSOX period of 2001, the companies in the sample as a group spent $31 \%$ of their total auditor compensation on other/miscellaneous services. However, in 2004, these companies used only $1 \%$ of their total auditor compensation for the purchase of other/miscellaneous services. A total of two hundred and seventy-two companies (or nearly 87 percent of the sample) reduced the amount of the purchase of other/miscellaneous services from their audit firms in the post-SOX period.

One hundred and seventy-seven companies (or 56.7 percent of the sample) reported no purchase of other/miscellaneous services from their audit firms in 2004. Among the remaining one hundred and thirty-five companies (or 43.3 percent of the sample) that purchased some amount of other/miscellaneous services from their audit firms, only thirteen companies (a little over 4 percent of the sample) reported paying more than 5 percent of the total auditor compensation for such services. Thus, a notable number of the companies (or 39 percent of the sample) managed to keep their purchase of other/miscellaneous services from their audit firms below the limit of the de minimis exemption permitted by the SEC (2003a), which would enable them to avoid seeking the pre-approval of the audit committees. However, it is possible that many of the companies may have purchased the consulting services from the newly formed consulting firms that were spun-off from the Big 4 CPA firms' auditing businesses (Lingblom 2002; Swartz 2002).

\section{Increase In Audit Fees In The Post-SOX Period}

A July 2004 survey of two hundred and twenty-four public companies by the Financial Executives Institute (FEI) showed that the respondents expected to pay 40 percent more to their external auditors for the internal control attestation work ${ }^{10}$ as a result of the section 404 compliance requirement of SOX and the relevant SEC rule (SEC 2003b). Results of our data analysis were in agreement with the findings of the FEI survey. In fact our results showed that the amount of the aggregate audit fees tripled for the sample, increasing from $\$ 972$ million in the preSOX period to $\$ 2,809$ million in the post-SOX period. During this period, the aggregate revenues of the sample increased by 17 percent while the aggregate audit fees paid increased by 188 percent, thus indicating that the increase in audit fees was not solely due to increased volume of business on the part of the audit clients.

The primary reason for this increase in audit fees could be the increase in the number of attestation hours now required on the part of the audit firms that are expected to attest to the management's report on the establishment and assessment of the effectiveness of the company's internal controls for financial reporting. Another reason for the steep increase in the audit fees could be the possible need for the audit firms to use "experts" to deal with the financial reporting intricacies arising out of the emergence of the new compliance requirements. Overall, the finding is in conformity with the results of prior surveys that audit fees would increase because of the section 404 compliance requirements (Levinsohn 2004; Salierno 2004; Parker 2005).

Our results also showed that such rise in audit fees was uneven across the sample. Only one company experienced an increase of less than 10 percent in its audit fees in 2004 compared to what it paid in 2001 . Three hundred and eight companies (or approximately 99 percent of the sample) paid audit fees that were more than 10 percent greater in 2004 compared to what they paid in 2001. Two hundred and sixty-eight companies (or 86 percent of the sample) paid audit fees that were more than 100 percent higher in 2004 compared to what they paid in 2001 . Fifty companies (or 16 percent of the sample) paid audit fees that were more than ten times greater in 2004 compared to what they paid in 2001. Also, fifty companies (or 16 percent of the sample) paid $\$ 10+$ million higher in audit fees in 2004 compared to that in 2001, with the increase in audit fees for a certain company being in excess of $\$ 73$ million. Only three companies in the sample experienced a decline in their audit fees in 2004 compared to what they paid in

\footnotetext{
${ }^{10}$ Source: "Sarbanes-Oxley Compliance Cost Estimates Soar 62\% Since January '04" available at http://www.fei.org/news/404_july.cfm.
} 
2001. Much of these statistics confirmed our expectations and were consistent with prior surveys of industry executives and audit firms (Scott 2003; Salierno 2004) that audit fees would rise higher in the post-SOX period. What is noteworthy is that the relative increase in audit fees was significantly higher than the estimates noted in previous surveys.

However, in view of the expanded definition of audit fees provided by the SEC (2003a), we cannot reject the possibility of misclassification of the overall fees between the categories audit fees and audit-related fees, which could present a misleading picture of the true increase in audit fees, caused by the section 404 compliance costs. Due to the limited disclosure requirements pertaining to the breakdown of auditor compensation, it is not clear if these companies have simply redesignated a large portion of their total compensation as audit fees to avoid undue attention that otherwise would arise from the purchases of large amounts of non-audit services from the auditors. As it stands presently, companies are providing general details of the services purchased and classified under each of the four categories of auditor compensation. In most cases, the terms used in the proxy statements are standard across the companies. However, it is not possible to tell if two or more companies interpret terms such as "internal control review" and "attestation services" the same way. Dickins and Higgs (2005) found in their research that the disclosures of auditor compensation were not adequate primarily due to inconsistencies in the classification of different services. They noted that, under the current disclosure rules, the same services are likely to be classified differently by different companies. Such inconsistencies could arise simply due to differences in the interpretations of which services are "typically considered to be provided by external auditors". The SEC's requirements of additional disclosure of total auditor compensation in the proxy statements may fall short if the same do not assure consistent disclosures across all companies, unless there are very detailed and clear definitions of the services in each category.

\section{SOX And The Shift In The Pattern Of Revenues Drawn By The Big 4 CPA Firms}

Along with the examination of the auditor compensation, this research also examined the change, if any, in the composition of the revenues received by the Big 4 CPA firms across the sampled companies in the years prior to and after the passage of SOX. Table 6 shows that in 2004, there was a clear change as to how each of the Big 4 CPA firms received their revenues from the four categories of auditor compensation across the companies in the sample.

In 2001, among the Big 4 CPA firms, PWC led the way by earning 54 percent of its revenues from "other services" provided to the sampled companies, followed by D\&T, KPMG and E\&Y that earned 39 percent, 26 percent and 20 percent, respectively. However, in 2004, D\&T topped the list by earning 2 percent of its total revenues from providing "other services" to the sampled companies while each of the other three CPA firms earned about 1 percent of their total revenue from "other services".

Table 6

Composition Of Total Compensation For Each Of The Big 4 CPA Firms

\begin{tabular}{|c|c|c|c|c|c|}
\hline & Audit Fees & $\begin{array}{l}\text { Audit-related } \\
\text { Fees }\end{array}$ & Tax Fees & Other Fees & Total \\
\hline D\&T (2001) & $34.7 \%$ & $16.3 \%$ & $9.5 \%$ & $39.4 \%$ & $100 \%$ \\
\hline D \& T (2004) & $72.3 \%$ & $11.2 \%$ & $14.5 \%$ & $2.1 \%$ & $100 \%$ \\
\hline E\&Y (2001) & $28.5 \%$ & $31.2 \%$ & $19.9 \%$ & $20.4 \%$ & $100 \%$ \\
\hline E \& Y (2004) & $69.3 \%$ & $12.5 \%$ & $17.1 \%$ & $1.1 \%$ & $100 \%$ \\
\hline KPMG (2001) & $35.0 \%$ & $10.9 \%$ & $28.2 \%$ & $25.9 \%$ & $100 \%$ \\
\hline KPMG (2004) & $76.0 \%$ & $11.3 \%$ & $11.9 \%$ & $0.8 \%$ & $100 \%$ \\
\hline PWC (2001) & $24.1 \%$ & $10.7 \%$ & $10.8 \%$ & $54.4 \%$ & $100 \%$ \\
\hline PWC (2004) & $77.2 \%$ & $8.4 \%$ & $13.1 \%$ & $1.3 \%$ & $100 \%$ \\
\hline
\end{tabular}


Further, in 2001, KPMG and E\&Y received approximately 28 percent and 20 percent, respectively, of their total revenues from the sampled companies by providing tax-related services compared to PWC and D\&T that had proportionately lower revenues of about $11 \%$ and $10 \%$, respectively, from tax fees. In the post-SOX period, E\&Y saw a small decline in its dependence on tax fees that decreased to 17 percent of its total revenues, while KPMG experienced a significant decline in this source of revenue that decreased to 12 percent of its total revenues from the sampled companies. In contrast, both D\&T and PWC experienced an increase in their proportionate revenues from the tax-related services provided to their audit clients. In the case of D\&T, tax fees went up by nearly 50 percent from 2001 to 2004, accounting for about 15 percent of its total revenues. PWC enjoyed a little more than 20 percent jump in its tax fees between the two years, ending at 13 percent of its total revenues in 2004.

KPMG was the only Big 4 CPA firm that experienced a small increase in its proportionate revenue from audit-related services by earning slightly more than 11 percent of its total compensation from such services in 2004, as against 11 percent in 2001. The other three firms saw a decrease in their relative revenues from audit-related fees, with $\mathrm{E} \& \mathrm{Y}$ experiencing the biggest proportionate decline.

All four firms increased their reliance on audit fees as the main source of revenue in 2004 as compared to that in 2001. Among the four firms, PWC had the largest percentage (77 percent) of its revenue derived from audit fees in 2004, while E\&Y had the smallest such percentage (69 percent). Also, PWC enjoyed the largest increase in its proportionate revenue from audit fees in 2004 which is surprising given that PWC had the smallest net gain in the number of clients between 2001 and 2004. The audit fee component of PWC's total revenue from the sampled companies jumped by nearly 220 percent compared to that in 2001. Similarly, KPMG had the second largest percentage (76 percent) of total revenues coming from audit fees in 2004, which was an increase of more than 100 percent from 2001. Both D\&T and E\&Y also saw their proportionate revenues from audit fees grow by more than 100 percent from 2001 to 2004, with E\&Y experiencing a bigger increase of 143 percent compared to D\&T's 108 percent increase.

In 2001, each of the Big 4 CPA firms relied relatively differently on the four components of its compensation. D\&T and PWC depended on audit fees and other fees to make up for more than 74 percent of their total revenues, with PWC depending much more on other fees compared to D\&T. KPMG earned a little more than 60 percent of its revenues from audit fees and other fees, and relied more on the tax fees than its three competitors did. E\&Y derived less than 50 percent of its total revenues from audit fees and other fees, and earned more from auditrelated fees. In fact, $\mathrm{E} \& \mathrm{Y}$ was the only firm that received the least amount of other fees in 2001. However, this picture changed in 2004 when three of the four Big CPA firms received more than 70 percent of their total compensation from the sampled companies in the form of audit fees, and the fourth firm, E\&Y, earned 69 percent of its total revenue as audit fees, perhaps due to the increase in the internal control attestation required by section 404 of SOX.

\section{SUMMARY AND CONCLUDING REMARKS}

In summary, the results of our examination showed the following: (1) in 2004, for all the sampled companies considered together, only 25 percent of the total auditor compensation was paid for non-audit services. This is a significant drop from the 71 percent of the total auditor compensation that was paid for non-audit services by the same group of companies in 2001; (2) in spite of the significant decline in the non-audit service fees paid by the sampled companies, the aggregate amount of compensation paid by these companies to their audit firms increased over the three-year period. Most of the increase in the total auditor compensation was caused by a phenomenal increase in the audit fees. About 86 percent of the sampled companies saw their audit fees increase by 100 percent or more during the three-year period under study; (3) the increase in the "audit fees component" was disproportionately large compared to the growth in the volume of business as measured by total reported revenues for 2004. While the aggregate revenues for the entire sample increased by 17 percent from 2001 to 2004 , the aggregate audit fees paid by the sample increased by 188 percent during the same period, thus indicating that there might be reasons other than a mere increase in the volume of business that caused the audit fees to rise during the period; (4) approximately 22 percent of the companies experienced a rise in their audit fees in spite of a decrease in their total reported revenues 
from 2001 to 2004; and finally, (5) the Big 4 CPA firms saw their revenue streams from the four categories of fees change in different proportions between the years 2001 and 2004.

An additional possible reason for the substantial increase in audit fees could be the increase in the audit work resulting from a heightened need on the part of the auditors to be more vigilant in the performance of their assurance duties especially in the aftermath of the recent corporate failures. The year 2001 marked the beginning of the outbreak of major corporate scandals that eroded billions of dollars from the stockholders' capital and pointed all the attention to the alleged failure of auditors in protecting the interests of stockholders. Consequently, in the recent years, audit firms may have been more diligent in their work and increased the scope and extent of their testing thus resulting in higher audit fees (Johnson 2005). In fact, this increase in audit fees appears to be a global phenomenon as shown by the results of an annual survey reported by Accountancy (Hanney 2005) that indicated that the FTSE100 companies are paying larger audit fees to their Big 4 auditors in the wake of the US scandals.

Based on our findings, it appears that while there has been a significant decrease in the non-audit service fees paid by the large companies, there also has been a significant increase in the absolute and relative amount of audit fees paid by these companies. We cannot conclude with certainty that the new legislation, SOX, followed by the relevant SEC releases, have been completely successful in curbing the revenue dependence of auditors on their audit clients. The economic bonding between auditors and their audit clients seems to remain undisturbed in terms of the absolute amount of auditor compensation except that the ratio of non-audit service fees to total fees, which was the point of contention for several years, has now diminished. The alleged high costs of the compliance with section 404 of SOX may have become a reality as seen from the rapidly increased costs of audits in the year 2004. However, there is some possibility that the auditor compensation disclosures of the companies may not be completely consistent across the companies and across time. Due to the differences in the interpretation of terms such as "attestation services," "auditrelated work," and "services reasonably expected to be provided by independent accountants," some of the fees paid to the audit firms may have been misclassified, perhaps unknowingly, in the annual proxy statements that were the source of the data in this research. To the extent that such classifications of the four components of auditor compensation were inconsistent, the results of this research may be tainted.

Future studies in this regard may compare similar data from smaller companies with that from larger companies such as the ones in this study to see if the results are consistent across the two sets of companies. Also more details may be investigated about the types of services provided under each category of the total auditor compensation to examine if companies are buying the same services as before and reclassifying them under a new name.

\section{REFERENCES}

1. Ascioglu, A., S. P. Hegde, and J. B McDermott. 2005. Auditor compensation, disclosure quality, and market liquidity: Evidence from the stock market. Journal of Accounting and Public Policy (July/August): 325-354.

2. Ashbaugh, H., R. LaFond, and B. W. Mayhew. 2003. Do nonaudit services compromise auditor independence? Further evidence. The Accounting Review (July): 611-639.

3. Ashbaugh, H. 2004. Ethical Issues Related to the Provision of Audit and Non-Audit Services: Evidence from Academic Research. Journal of Business Ethics (June): 143-148.

4. Beatty, R. P. 1993. The economic determinants of auditor compensation in the initial public offerings market. Journal of Accounting Research (autumn): 294-302.

5. Behn, B. K., J. V. Carcello, D. R. Hermanson, and R. H. Hermanson. 1999. Client satisfaction and big 6 audit fees. Contemporary Accounting Research (winter): 587-608.

6. Cohen, J. and S. Vecchio. 2004. Ripple Effects of the Sarbanes-Oxley Act. The CPA Journal (February): 36-40.

7. Craswell, A. D. J. Stokes, and J. Laughton. 2002. Auditor independence and fee dependence. Journal of Accounting \& Economics (June): 253-275.

8. Dee, C., A. Lulseged, and T. Nowlin. 2002. Earnings Quality and Auditor Independence; An Examination Using Nonaudit Fee Data. Social Science Resource Network (May). Available at http://papers.ssrn.com/sol3/papers.cfm?abstract_id=304185.

9. DeFond, M. L., K. Raghunandan, and K. R. Subramanyam. 2002. Do nonaudit service fees impair auditor independence? Evidence from going concern audit opinions. Journal of Accounting Research (September): 1247-1275. 
10. Dickins, D. and J. Higgs. 2005. Interpretation and use of auditor fee disclosures. Financial Analysts Journal (May/June): 96-102.

11. Frankel, R., M. Johnson, and K. Nelson. 2002. The relation between auditors' fees for nonaudit services and earnings management. The Accounting Review (December): 71-103.

12. Ferguson, M. J., G. S. Seow, and D. Young. 2004. Nonaudit Services and Earnings Management: UK Evidence. Contemporary Accounting Research (winter): 813-841.

13. Firth, M. 2002. Auditor-provided consultancy services and their associations with audit fees and audit opinions. Journal of Business Finance \& Accounting (Jun/Jul): 661-693.

14. Geiger, M. A. and D. V. Rama. 2003. Audit Fees, Nonaudit Fees, and Auditor Reporting on Stressed Companies. Auditing: A Journal of Practice \& Theory (September): 53-69.

15. Gullapalli, D. 2005. Moving the Market -- Tracking the Numbers / Outside Audit: Audit Fees Are on Rise As Companies Pony Up; Payments for Consulting And Other Services Shrink, In Big Change From 2000. Wall Street Journal. (Eastern edition). New York, N.Y.: Mar 25, 2005, p. C.3.

16. Hanney, B. 2005. FTSE 100 audit fees jump 22\%. Accountancy (September): 5.

17. Hogan, C. 1997. Costs and benefits of audit quality in the IPO market: A self-selection analysis. The Accounting Review (January): 67-86.

18. Johnson, C. 2005. Higher Audit Fees, More Accountability: Sarbanes-Oxley, Three Years Later. Washington Post (July 30, 2005), Page D01. Available at http://www.washingtonpost.com/wpdyn/content/article/2005/07/29/AR2005072901741.html

19. Kelly, J. 1999. Fees for other services climb. Financial Times, London, UK: September 23, 1999, p. 12.

20. Krishnan, J., H. Sami, and Y. Zhang. 2005. Does the provision of nonaudit services affect investor perceptions of auditor independence? Auditing: A Journal of Practice \& Theory (November): 111-135.

21. Levinsohn, A. 2004. Section 404 costs soar. Strategic Finance (September): 63-64.

22. Lingblom, M. 2002. Consulting spin-off. CRN (981): 4.

23. Parker, A. 2005. Audit fees double for big four: Complying with US legislation proves bonanza for accounting firms: Survey finds companies spent Dollars 5m-Dollars $8 \mathrm{~m}$ each to meet rules in 2004. Financial Times, London, UK: Feb 9, 2005. p. 19.

24. Raghunandan, K. 2003. Nonaudit services and shareholder ratification of auditors. Auditing: A Journal of Practice \& Theory (March): 155-163.

25. Raghunandan, K., W. J. Read, and J. S. Whisenant. 2003. Initial evidence on the association between nonaudit fees and restated financial statements. Accounting Horizons (September): 223-234.

26. Reynolds, B. 2005. POBA confirms Big Four nonaudit fee loss. Accountancy (March): 11.

27. Salierno, D. 2002. Nonaudit services on the decline. The Internal Auditor (December): 16.

28. Salierno, D. 2004. Section 404 costs soar. The Internal Auditor (October): 19-20.

29. Scott, A. 2003. Audit fees expected to rise. The Internal Auditor (August): 13-14.

30. Simon, D. T. 1997. Additional evidence on the large audit-firm fee premium as an indication of auditor quality. Journal of Applied Business Research (fall): 21-29.

31. Stock, H. 2002. Most Companies Still Pay Audit Firms for Non-Audit Work. Investor Relations Business (New York, NY: December 2, 2002): 1.

32. Swartz, N. 2002. IBM to purchase PricewaterhouseCoopers Consulting. Information Management Journal (Sept/Oct): 12.

33. Taylor, M. H. and D. T. Simon. 1999. Determinants of audit fees: The importance of litigation, disclosure, and regulatory burdens in audit engagements in 20 countries. The International Journal of Accounting (34): 375-388.

34. U. S. Congress. 2002. Sarbanes-Oxley Act of 2002, H.R. 3763.

35. U. S. Securities and Exchange Commission. 2000. Revision of the Commission's Auditor Independence Requirements. Final Rule Release No. 33-7919, November 21, 2000.

36. U. S. Securities and Exchange Commission. 2003a. Strengthening the Commission's Requirements Regarding Auditor Independence. Final Rule Release No. 33-8183, January 28, 2003.

37. U. S. Securities and Exchange Commission. 2003b. Management's Reports on Internal Control Over Financial Reporting and Certification of Disclosure in Exchange Act Periodic Reports. Final Rule Release No. 33-8238, June 18, 2003.

38. U. S. Securities and Exchange Commission. 2004. Management's Report on Internal Control over Financial Reporting and Certification of Disclosure in Exchange Act Periodic Reports. Final Rule Release No. 33-8392, February $24,2004$.

39. Weil, J. and J. Tannenbaum. 2001. Big Companies Pay Audit Firms More for Other Services. Wall Street Journal (Eastern Edition), New York, NY: April 10, 2001, p. C.1.

40. Weil, J. 2004. Moving the Market -- Tracking the Numbers / Outside Audit: Auditing Firms Get Back to What They Do Best; Fees Jump, Procedures Expand as Accountants Shed Nonrelated Services. Wall Street Journal (Eastern edition), New York, NY: Mar 31, 2004, p. C.3. 